\title{
Graduate Unemployment in Ghana: Challenges and Workable Strategies
}

\author{
Emmanuel Amponga \\ eampong17@gmail.com
}

E. P. College of Education, Bimbila. Ghana W/A

\begin{abstract}
This paper examines the worsening graduate unemployment phenomenon in Ghana considering the negative effects associated with this setback and strategies that can be adopted to address them. Library research is the method used to collect the data. Globally, more graduates are found to be youthful but are plagued with the problems of unemployment, and Ghana is of no exception. This paper observes that the graduates have something to offer but have no jobs and are faced with the harsh realities of life. Ghana is not insulated to the negative effects associated with unemployment like armed robbery, prostitution, cybercrime and others. The paper recommends that instituted policies must aim at innovating Ghana's educational curriculum to make it more entrepreneurial, the government creating opportunities to empowering the youth, private enterprises creating more jobs, and the unemployed graduates themselves being creative and not waiting for the government and co-operate bodies to offer them jobs.

Key words: Unemployment, unemployed graduates, youth, career development, negative effects, and strategies.
\end{abstract}

\section{Background to the Study}

Plecher, (2020) asserted that in 2019, the unemployment rate in Ghana was at approximately 4.33 percent of the total labor force. The unemployment rate is the percentage of a country's labor 
force that are without jobs but are available to work and actively seeking employment. Ghana's unemployment rate is above the worldwide unemployment rate, and compared to other Sub-Saharan African countries and other regions, Ghana has a relatively average rate of unemployment. Biney, (2015), opined that the economy of Ghana fared well in the 1960s and early 70s such that the issue of unemployment of university graduates was not a problem. This was because, manufacturing industries built by the Convention People's Party (CPP) government under the leadership of late President Dr. Kwame Nkrumah were in operation. There were number of state-owned industries operating in the regions and districts of Ghana respectively, such that the youth who complete school could seek employment from, and subsequently become employed. For instance, Bonsa Tyre Company Limited, Ghana Rubber Estate Company and Aboso Glass Factory were in full operations at the former Wassa West District now Tarkwa-Nsuaem Municipal alone, creating job opportunities to trained engineers, technologists, administrators and even ordinary factory hands. More than 600 of such state-owned and managed industries have collapsed, rendering many people jobless and unemployed. Tsekpo, (2014), cited in Biney (2015), perceiving unemployment from the measurement perspective opines that unemployment covers people who are: out of work, want a job, have actively sought work in the previous four weeks and are available to start work within the next fortnight; or out of work and have accepted a job that they are waiting to start in the next fortnight. What these mean is that a typical economically active labour market participant can be classified as employed or unemployed within days or weeks or months. The pendulum can swing between these categories in quick succession.

According to Pillai (2011:29) "unemployment can be defined as a state of worklessness for a man fit and willing to work". Basically, graduate unemployment is a jobless situation with a person with an academic degree. According to the BBC (2011:6), the International Labour Organization(ILO) has reported that the world's economy is on the verge of a new and deeper jobs recession that may ignite social unrest. The report continues to say that it will take at least five years 
for employment in advance economies to return to pre-crisis levels. In its world report of 2011, the International Labour Organization (ILO) said a stalled global economic recovery had begun to "dramatically affect" labour markets. DeutcheWelle TV recently reported at its website that some countries in the Eurozone are experiencing increasing rate of unemployment. The report mentioned countries like Spain, Portugal, Greece and Italy. Pele (2011:38) “in Ghana reliable data is difficult to find but estimates from the world bank indicators put the number of youth at about $65 \%$ of the unemployed" and the number of unemployed graduates is part of the figure. According to Jonah (2011), Ghana's Labour Commission estimates the unemployed graduate figure to be a staggering 700,000 to date.

The nation Ghana has reached a lower middle income economic status and cannot be well protected from the world's threatening financial crisis which is seriously collapsing existing jobs and combating the creation of new jobs. It stands to reason that the number of unemployed graduates will continue to rise or increase owing to the fact that the government may find it difficult creating more jobs to take care of the teeming graduates who are jobless in order to secure a better life for the unemployed graduates in particular and the citizenry in general. It must be categorically stated that graduate unemployment is one of the challenges that successive government have tried to bring under control but have chopped little success (Gariba 2012:48). Graduates are people who have enjoyed government subventions while they were in school. Some receive partly free education from the basic level to the secondary level as can be seen happening in the northern part of Ghana. Logically, graduates are people who are to give to society what they have received from it.

Pele reported that:

Several reasons account for the sudden explosion of unemployed youth. The most significant being the unwillingness of Governments to acknowledge its reality and plan towards it by putting in place deliberate mechanisms to 
address it. Another major cause of the unemployed phenomenon, especially, in poor countries is that the private sector is not growing at a rate fast enough to generate the needed jobs (Pele 2011, P.38)

It is rather unfortunate that the right atmosphere or environment has not been created for most of the graduates to perform this civil duty. Graduates are to offer societies their expertise or acquired knowledge, skills, wisdom, values, attitudes and principles in whatever capacity they find themselves at the work place but majority of them are jobless. The rippling effect of this worrying trend is the retrogression of the nation's development.

Graduate unemployment and under-employment, therefore, puts a heavy cost on the nation's economy. Some of the heavy cost the nation must bear is the non-retrieval of the money spent on the education or training of these graduates or intellectuals because they have not secured jobs. In addition, the menace cannot ensure the widening of the tax net for more revenue into the government's chest because no jobless person can pay any significant amount of money as tax. In furtherance, the upsurge of practices or occurrences like prostitution, armed robbery, cyber-crime, abject poverty, homelessness, brain-drain, to mention but a few, and their attendant health problems like infection of H.I.V and AIDS and other sexually transmitted diseases, hypertension, mental derailment, typhoid fever, malaria and others. Attendant financial problems like the government's spending on the above-mentioned health problems and funds to curb crimes committed by some of the unemployed graduates like armed robbery, rape, drug abuse and the like cannot also be ruled out.

Abugri (2011) reported that Aryeetey has commented that "50 percent of the country's universities graduates are unlikely to find employment for two whole years after their national service and 20 percent of the number will have to wait for three years to get jobs". This revelation of Professor Aryeetey, the former Director of the Institute of Statistical Social and Economic Research, University of Ghana, Legon, cannot be disputed or swept under the carpet.According to Abugri, (2011:7) "there is already a large amount of unemployed university graduates walking the 
streets and that there is even a National Association of Unemployed Graduates". He added that "the cost of university education in Ghana is downright prohibitive, so why would people invest in education up to the university level and then remain unemployed?"

The rationale for undertaking this seminar paper is in two folds. In the first place, the study will identify or look at the negative effects of graduate unemployment like cybercrime, poverty, prostitutions, armed robbery, high cost on the economy, drug abuse, brain-drain, just to mention a few. Secondly, the study will look at the strategies that can be adopted to overcome the negative effects. Some strategies like employers impressing on academic institutions, especially, the tertiary institutions to increase focus on areas like tourism, leisure and hospitality, secretarial studies, information technology, entrepreneurship, small business management, to mention but a few; the government creating new jobs to absorb the teeming unemployed youth and also creating an enabling environment for private businesses; and the graduates themselves being creative to establish their own jobs.

As an adult educational practitioner, it behooves on the researcher to device some mechanisms which can create jobs for the unemployed youth, especially, the unemployed graduates in order to realize the improvement in the quality of life of the unemployed graduates in particular and the society at large. The researcher would want to organize career guidance seminars, workshops, and fora, for the unemployed graduates to furnish them with the information in entrepreneurship and communication skills and how to practicalize the information in their everyday activities so as to turn their fortunes around. The main variables to discuss in this paper are some of the negative effects associated with this negative trend or development (graduate unemployment) and some strategies that can be adopted by the academia, the government, cooperate bodies or private employers, the unemployed graduates themselves, adult educational institutions and others to drastically reduce the number of unemployed graduates in the Ghanaian society. The method through which the information about this research was collected was by library 
research which saw the collection of information from sources such as text books, the dailies and the internet.

Graduate unemployment is unemployment among people with an academic degree. An unemployed graduate is, therefore, a person who holds a degree certificate and is looking forward to landing a job in order to turn his/her fortunes around. This section of the paper will look at some of the negative effects of the menace (graduate unemployment) and strategies to curb them. The negative effects and strategies will both be broken down into different sub-topics and each sub-topic shall receive some thorough interpretative discussion on it. The negative effects would be discussed first and the strategies would then follow.

\section{Negative effects of Graduate Unemployment}

\section{- Social and Political Instability}

According to Idris (2016) cited in (Enyonam, 2017), a U.S. Agency for International Development (USAID), (2005:4) report on youth and conflict identified unemployment as a risk factor for young people, asserting that 'young people often participate in violence because membership in extremist organizations provides immediate economic benefits, because violence itself offers opportunities for economic gain through direct payment or looting, or because conflict promises to open up longer term economic options, for example, through patronage if “their” ethnic or religious group captures power'.

Again,

Long unemployment experienced among young people can also be a source of social and political instability, especially, if these young people are educated. Recent events in the Middle East now popularly referred to as the "Arab Spring", attest to the power of this section of the youth to articulate and stand up for their right. Therefore, the high unemployment among our graduates must be considered as a national security issue (Gariba2012, P.48). 
Ghana as a nation has been lucky not to have experience demonstrations or revolts by unemployed graduates that could create political and social instability. Nevertheless, if this menace is left unchecked by the people at the helm of affairs and it is allowed to continue to have a field day in the labour sector, then this nation can be said to be sitting on a time bomb. The demonstrations staged intermittently by members of the unemployed graduates is but a clarion call to all and sundry to wake up and do something about the menace so as to maintain the relative peace the nation is currently enjoying.

\section{- Criticisms against Tertiary Institutions, especially, the Universities.}

Biney (2015) conducted a research on the topic "Exploring graduate unemployment problem in Ghana: Challenges and Strategies". Semi-structured interview schedule was designed and administered to 40 level four hundred undergraduate students pursuing Bachelor of Science Administration and Bachelor of Arts degree programmes at University of Ghana, Legon. The study sought the views of students on challenges that confront unemployed University graduates and strategies that can be put in place to improve job creating opportunities for them. On whether the respondents stand the chance of securing job after school, nearly all (94 percent) of the respondents were in the affirmative. The respondents were of the view that the kind of education they were receiving would offer them jobs. For the respondents to confidently assert that the education they are receiving will guarantee them jobs, is in itself motivating, and encouraging as well. It means therefore that the university graduates while at school will learn to master what it takes to secure or create jobs for themselves at the workplace. On perceived challenges confronting university graduates today, multiple responses were indicated by the respondents. The responses that emerged are summarized below:

On Perceived Challenges Confronting University Graduates, here are the percentages with the various items in the interview schedule: 1. Lack of practical, technical and entrepreneurial skills- 61\%; 2. Most of what are learnt are theories-based- 39\%; 3. High cost of credit or start-up capital for business- 30\%; 4. Lack of job opportunities- 26\%; 5. Courses not linked to industry and 
business sectors- 26\%; 6. Tendencies of engaging in social vices are high- 26\%; 7. Businesses demanding from graduate work experience- 21\%; 8. Lack of broad social network- $15 \%$. Note: Multiple responses were made $N=33$. Source: Field Data, 2014. According to the above information, the most perceived challenge of lack of practical, technical and entrepreneurial skills was revealed by 61 percent of the respondents. This response contradicts the earlier response made by nearly all (94 percents) of the respondents that they stand a better chance of securing and creating jobs themselves, considering the fact that they lacked entrepreneurial skills and spirits. The result confirms Kwapong (cited Sottie, 2014) assertion that educational institutions in Ghana should incorporate entrepreneurship into any discipline taught so that the students in our institutions would graduate with an entrepreneurship mindset (Biney, 2015, P.11).

In furtherance, tertiary institutions, especially, the universities, have come under serious bashings or criticisms by the general public in the media landscape for being responsible for authoring high graduate unemployment.

The tertiary institutions are accused of turning out products that cannot be absorbed by the labour market. In fact, historically, universities have not responded very well to labour market and this has led many countries to put in place systems to work transition bridges by introducing institutions such as vocational training institutions, community colleges, technical institutes and polytechnics. This arrangement is an admission that there is a missing link between the academy and the world of work (Gariba2012, P.48).

Of a truth, learners of the universities are given information more in the theoretical form than in the practical form. This makes it difficult for graduates to relate the academic information to real life situations or practicalize the academic information in order to create jobs for themselves and others. Most often than not, the universities do not liaise with employment institutions on engagements of their students in vacation attachments. This situation makes tertiary education more 
bookish than job oriented. Some graduates have not been trained to acquire some relevant or prerequisite skills like interview skills, good speaking and writing skills, entrepreneurial skills, preparation of curriculum vitae, résumés and the like which employers initially look for in a prospective employee. This makes it impossible for employers to employ these calibers of graduates thereby increasing the population of unemployed graduates.

\section{- Armed Robbery}

Tankebe and Boakye (2019), conducted a research on the topic: 'Are murder and robbery on the increase in Ghana? Analysis of police crime statistics?' The researchers analyzed trends in violent crimes in Ghana between 2012 and 2018. The results of the study shown that robbery rates are at their highest in seven years; however, murder rates are the lowest over the period covered. The implication of the study is that understanding where and when these violent crimes are concentrated can help Police target their limited resources more effectively. Conklin (1972) cited in Lhayea, (2016), developed four types of armed robbers, namely: Professional, Addict, Opportunist, and Alcoholic. The last category is Alcoholic robbers. In comparison to the other types of robbers, alcoholic robbers do not exhibit any commitment toward stealing. They only steal when they are under the influence or when their situation impairs them from securing an employment. More so, alcoholic robbers do not exhibit any plan before robbery (Conklin, 1972; Woodhams and Toye, 2007).

The spate of armed robbery is very alarming in the Ghanaian society. One cannot sweep under the carpet the fact that one of the causes of this worrying development is unemployment among the youth. According to the Ghana Police Service, armed robbery in this modern time is very sophisticated which makes the clamping down of the menace quite a herculean task to the Service. What makes the armed robbery sophisticated? One cannot rule out the fact that "educated minds" are now members of these gangs and are able to device strategies to counter the intelligence of the Police Service. It is significant to say that the educated people among the armed robbers can easily learn how to use sophisticated weapons in robbery than their uneducated or illiterate counterparts. 
The repercussions of armed robbery are not far-fetched. Victims of armed robbery are maimed, raped or lose their precious lives and personal effects.

\section{- Cyber Crime}

Boateng, Olumide, Isabaliya, and Budu, (2011) researched on the topic: 'Cyber Crime and Criminality in Ghana: Its forms and implications.' The researchers investigated the prevalence of cybercrimes (called 'Sakawa') in Ghana and examined its forms and implications. Using qualitative approach, they explored efforts by organizations and government agencies in Ghana towards curtailing cybercrimes in terms of apprehension, prosecution, reporting, and law enforcement. Findings from the research showed that although awareness of cybercrimes is on the increase, the crimes mostly go unreported. The Ghana Police Service which is the organ of government responsible for arresting and prosecuting cyber criminals also lack the technical know-how and adequate legal support to effectively discharge their duties. The researchers recommended that a multi-stakeholder effort and appropriate technical training for the Police and supportive legislation are required. For online financial transactions, developing strategies which incorporate offline business qualification requirements may be the necessary starting point. Since the perpetrators are young and have some degree of technical competence to commit computer-related crimes. This brings to question the need for appropriate youth development programs which utilize their technical competencies.

A new way of robbery is the cybercrime. The perpetrators of this crime do not use arms in robbing their victims. On the contrary, they deceive their victims as both the perpetrator and the victim exchange pertinent information on the internet. The perpetrators, we are told, are not only backed by some spiritual forces but are also highly intelligent. This level of intelligence can only be seen in somebody who has acquired some appreciable level of education like tertiary education. It is very worrying to hear that quite a number of unemployed youth in Ghana are into this illegal 
business. Victims lose huge sums of their monies or valuables to the perpetrators of this crime. Some victims upon realizing that they have been duped commit suicide or lose their minds.

\section{- Prostitution}

Bindel reported that:

Over the past two decades, I have interviewed scores of men who pay for sex-in large brothels and illegal massage parlors, and on the street. I have heard every justification from these men, including one about helping women feed their kids with the money exchanged for sex. Although prostitution-both buying and selling sex-is illegal across most of the U.S., very few sex buyers are ever arrested. Prostituted women, however, are heavily and unjustly criminalized, despite evidence that the vast majority are coerced and exploited into the sex trade (Bindel, 2019).

The research by Bindel (2019) has clearly shown that a vast majority of prostitutes are lured and exploited into the sex trade probably as a result of they not landing better jobs or not having any other jobs. A graduate without any job is very susceptible to engaging in prostitution for survival and there will be no surprise to realize that some of the prostitutes' participants in Bindel's research are unemployed graduates. Prostitution in all its forms has received a massive patronage or subscription of some unemployed youth who may be graduates. It is even no news that some university male and female students are practicing prostitution. This negative habit of these students can have a hold on their lives and some will continue to practise prostitution after finishing the university. The harsh realities of life are experienced by the unemployed graduates and some may see prostitution as the only way out. In effect, prostitution is now the job or the profession for some unemployed graduates. The negative effects of prostitution can be seen in the rising level of infection rate of HIV and AIDS and other sexually transmitted diseases among the practitioners themselves and their customers or patrons. This makes the government to spend more on how to 
minimize the infection rate of HIV and AIDS among the citizenry. Research has shown that the practice of prostitution is one of the major ways by which people get the HIV virus.

\section{Strategies to curb graduate unemployment}

In the first place, Donkor (2014), cited in Biney (2015), asserted that proper recapitalization of rural enterprises programme and state funding organisations, including Micro-Finance and Small Loan Centre (MASLOC) would go a long way for university graduates to secure start-ups capital to create jobs for themselves and others. Proper funding of Venture Capital Trust Fund (VCTF) among others, would sufficiently cause the youth to tap into the sources to create their own businesses and become self-employed. The Economist (2013) points that out the Germany's long established system of vocational training and apprenticeships do just that. Secondly, the agriculture sector, including fisheries and livestock, if properly revamped, would go a long way in creating sustainable jobs to the teeming university graduates. The sector will become attractive to the young university graduates to build their careers in the various supply chain in the sectors. This is because the supply chain involved in the agriculture sector will be properly developed so as to provide numerous opportunities for the youth to create jobs for themselves (Biney, 2015).

Thirdly, Pele (2011) reported by saying that "the implication of unemployment and for that matter graduate unemployment for many countries is too dangerous and serious to ignore. The main recommendation by experts has, therefore, been for governments to put in place youth employment or entrepreneurial schemes". The government of Ghana is doing much to curb the spate of the graduate unemployment becoming alarming. Some of the ways have been discussed below Most importantly, the local enterprises skills development programme (LESDEP) is the brainchild of the government. LESDEP train people in hairdressing, mobile phone repairs, catering, transport services and dressmaking. After receiving training, the graduates are presented with start-up packages. The aim of LESDEP is to offer employment to the teeming unemployed youth in this country thereby alleviating poverty with the affected persons. The unemployed graduates can take advantage of this opportunity to land a job. Fourthly, the National Youth Employment Programme 
has come at a better time to contribute to the reduction of the number of unemployed youth, especially, unemployed graduates in the society. According to Pele (2011:38 \& 40) "the NYEP was a brainchild of the national security which at a time realized the scale and enormity of the youth unemployment in the country which was rising. For the first time, the graduate unemployment was experienced on a large scale. From 2007 to date, the NYEP has registered more than one million youth who have registered to participate due to their inability to find jobs anywhere". After receiving training, graduates are presented with tools and other inputs to help them start jobs created by the programme. The recruits are given allowance at the end of every month in order to make ends meet.

In addition,

the Gender Responsive Skills and Community Development Project (GRSCDP) scholarship for female trainees at Community Development Institutes as a well as other identified technical institutes which are found in 59 deprived districts across the country to enroll them into male dominated areas of work such as plumbing, auto mechanic, electrical installation among others. The GRSCDP has so far given scholarships to little over 500 girls from extremely poor households to pursue technical skills programmes including plumbing, masonry, carpentry and the likes. The training is aimed at getting more girls into fields with higher prospects of career advancement and improved income which hither to were considered male dominated areas (Gender desk 2013, P. 11).

This programme is gender biased but it doesn't prevent, especially, female unemployed graduates to take advantage of it to turn their fortunes around thereby the programme partly mitigating against the menace. This move by the Government of Ghana under the tutelage of the Ministry of Gender, Children and Social Protection is laudable and must be given all the needed support by all stakeholders since the programme can create so many jobs for the youth,especially, 
for the female graduates who will be able to establish their own businesses and train several other people thereby creating more jobs in the society.

Furthermore, Gariba, (2012:48) another strategy that can be adopted to deal with the menace is that is that "the tertiary institutions should focus on providing students with fundamental skills such as problems-solving, analytical techniques, creative thinking and innovation, so that they are adaptable to new work environments. If Ghana is to move to the next stage of its development, these high-levels skills and qualities are needed in her labour market rather than specific job skills". In addition, Gariba, (2012:48) suggested that "as a nation, there is the need to put in place national school-to-work transition programmes that will prepare tertiary graduates for jobs in the labour market". Of a truth, one cannot relegate to the background the fact that major part of the curricula of tertiary institutions must be vocational or job oriented if the problem of unemployed graduates can be nip in the bud. Furthermore, there is the need for students in tertiary institutions to experience some attachments or internships in both government and private employment institutions for the students to be equipped with the knowledge of how the different jobs are carried out or done at the work places. This strategy can make the students after completing their courses more marketable and above all establishing their own businesses.

Moreover, Enyonam, (2017) opined that skills acquisition is important, helpful, lucrative, and worth promoting. Skills training are important ways of investing in the youth. The skills the youth acquire will help them to be publicly employed and also be self-employed. Both government and non-governmental organizations are expected to contribute their quota in helping the youth to acquire skills. They can offer that in the form of scholarships to the youth. Practicing this will help the youth to earn money for their living and also to train others. Following this trend will help in the reduction of the percentage of the world's unemployed youth. Furthermore, adult educators must be able to roll out interventional programmes to individuals, groups and communities as a way of reducing the cost of living and raising the standard of living of the people. After establishing or pinpointing the felt needs of the communities, adult educators must work hand in hand with the 
people in the communities by providing the communities with the needed professional counseling on how to utilize the local resources in order to create jobs and regular source of income for the teeming unemployed youth who shall receive training, tools and equipment, funds, infrastructure to establish their own businesses. Community people, on their part, may contribute their widow's mite or some little material resources like money, devotion of their time and the use of their energy to ensuring the actualization of the dreams of the adult educators which in effect can turn the fortunes of the community people around. The researcher is of the view that this move by adult educators can minimize the occurrence of youth unemployment and for that matter graduate unemployment in the Ghanaian society.

Again, the private sector (micro, small and medium enterprises) must be provided with the enabling business environment by the government like tax respite, no political hunting of businesses that are perceived to be against the government in power, soft loans given to private businesses by the banking institutions, among others. These motivational offers can empower private businesses to maximize profit and also spread their tentacles which in effect will see to the recruitment of more qualified people who need jobs like the unemployed graduates in our society. It is significant to say that the private sector is the heartbeat of national growth.

In furtherance, it is worth mentioning here that the unemployed graduates themselves must be bold to venture into credible businesses or trades like farming, retailing, teaching, manufacturing, just to mention a few. The unemployed graduates should not allow the initial failures they may experience in their businesses to deter them from breaking the shackles of unemployment off their feet and hands. The unemployed graduates should also try and use the knowledge they have acquired in school to establish jobs of their own and should not despise their small beginnings in order to confirm the truism that "little drops of water make a mighty ocean. Enyonam (2017) opined that information marketing is an important skill that can transport the Ghanaian unemployed youth from rag to riches. The most important thing about information marketing is that it does not just secure employment for the youths but as well develop people who are into it on various areas. Most 
of the youths who are into information marketing today did not pay anybody to acquire the skill but learnt it through research work on the internet. This has been lasting solution to youth unemployment in neighboring states.

Moreover, creating opportunities for university graduates through provision of knowledge, skills and attitudes in entrepreneurship is another practical approach to making them become selfemployed. The university graduates should be able to take moderate and calculated risk based on facts and information to set up small scale businesses. The graduates should be passionate, thus, be driven by compelling vision of creating viable jobs for themselves and others. This is one of the surest ways to overcome the thorny issue of joblessness or unemployment confronting today's graduates from our universities in Ghana (Biney, 2015).Boye, (2012) reported that young and old entrepreneurs should be bold to approach the Business Development Services Fund (BDSF) and MASLOW outfits created by the government to give financial and institutional support to micro, small and medium enterprises (MSMES) for assistance. The Buabengs, the KwadwoSarfos, the Ocrans, the Ken OforiAttas, the Uncle Ebos, the Otabils, to mention but a few, also began their businesses on a very humble pedestal but are now living legends or heroes or heroines in their business fields. The unemployed graduates must take inspiration from these people and it will surprise themselves and all and sundry what they will be able to use their polished talents to do as far as creating jobs for themselves and others is concerned. Another plea to unemployed graduates is that there is the need to acquire basic business knowledge in the critical areas of bookkeeping, product costing, business planning and marketing.Lastly, the government of Ghana must devise means to stopping corruption which in turn will prevent the governing body, other institutions and private individuals from engaging in a criminal activity such as money laundering. Strong anticorruption bodies should be established and they are to be independent of government. Punishing any government official caught in corrupt practice is an important tool that can be used to create employment for the Ghanaian youth. The fight against corruption will keep more funds in the country and the fund used to generate employment for the youth (Enyonam, 2017). 


\section{Implications for Adult Education}

The problem under study has some implications for adult education in terms of theory and practice, and how to shape the government's socio-economic policies. In the first place, tertiary institutions which are more or less adult educational institutions are to review some of the aspects of their curricula. The view is that some academic programmes have little or no value to the current job market. Some concerned Ghanaian citizens, especially, employers are making their voices heard more in the media landscape about the issue of the universities producing half-baked graduates who cannot fit into the job market. Their concern or suggestion is that the universities should focus on courses like entrepreneurship, information communication technology, small business management, and the like which will equip the graduates the universities turn out with employable skills in other to make the graduates marketable and entrepreneurs thereby minimizing the occurrence of the phenomenon of graduates' unemployment. Moreover, tertiary institutions are admonished to liaise with co-operate bodies and governmental employing institutions to give opportunities to tertiary students to have vacation attachment programmes which will prepare the students for jobs in the labour market after graduation. Nevertheless, the researcher side with the statement given by George Sydney Abugri, a columnist of the daily graphic's September 16, 2011 edition that: "a reconfiguration of universities' curriculums to make graduates readily marketable should in no way interfere with the very critical traditional role of the universities as centers for the building of a critical, national mass of intellectual scholars and researchers".

Secondly, "the adult populace in the Ghanaian society is to stop placing high premium and rewarding academic credentials instead of skills. The more academic credentials to one's name, the more successful a product of our educational is perceived to be" (Abugri 2011, P.7). Yet, when some of these graduates are employed their performance becomes nothing to write home about resulting in their dismissal or losing their jobs. It is about time that society conscientize graduates in the making and for that matter future job seekers that the society is looking for highly skilled 
individuals who will be successful at the workplace and not just graduates who come along showing a couple of diplomas or degrees and want a job. This will make would-be graduates to prepare themselves adequately in some other areas like computing, preparation of curriculum vitae or résumés, preparation for interview, ability to speak and write good English which are essential or pre-requisite skills employers look for in job seekers in this contemporary labour world.

Thirdly, according to Aryeetey (2011:7) “inadequate government attentions have been given to the problem of unemployment generally and that existing policies are not likely to lead to any major creations of new jobs. The governments of Ghana's policies on employment are designed for a free market economy whereas nothing like a free market exists in Ghana economy”. This information given by the former director of the Institute of Social Statistics and Economic Research, University of Ghana, Legon, should be taken seriously and that the citizenry must impress upon the people they have elected into power to make critical policies in the area of job creation and execute them for the betterment of the Ghanaian society. Thenation's material and human resources have been vested into the government's hands and the government must harness these resources to lure to the benefit of all, especially, graduate job seekers. The government should not fail otherwise the people who voted her into power will be the same people who will vote her out of power.

Lastly, adult educational institutions and for that matter adult educational practitioners must not rest on their oars since the challenge of graduate unemployment has almost become a yearly affair. Graduates are turned out yearly only to be members of no professional association but members of Unemployed Graduates Association of Ghana. It is, therefore, incumbent on adult educators to intensify their adult functional literacy and community development programmes in various communities across the length and breadth of Ghana in order to empower the citizenry to take their destinies into their own hands by harnessing the local resources to their benefit. One of Malcolm Knowles theories of adult andragogy is that adults can learn if the learning environment and curriculum are made conducive and tailored to their needs. Adults educators, specifically, can organize fora, workshops on career development or entrepreneurship for the members of the 
Unemployed Graduates Association of Ghana to equip them with employable skills which can result in self-employment or being employed by both governmental and private enterprises. Patrons of these workshops, seminars and fora can be supported by the government with a seed capital and some logistics to go into self-employment and later employ other jobless people in the communities.

\section{Conclusion}

Graduate unemployment is still a challenge many governments all over the world are battling with. Politicians in both developed and under developed worlds like U.S.A. and Ghana, respectively, are tasked by their fellow citizens to create jobs for people who deserve or qualify to land a job.The People and graduates alike having jobs will contribute to a stable government and improvement in the quality of life for all and sundry. If these jobs are not available or existing it brings about a lot of challenges or negative repercussions like abject poverty, prostitution, drug abuse, cyber-crime, armed robbery, governments' huge spending or expenditure on health and security of the people, brain drain, broken homes, homelessness, ritual killings for money, to mention but a few. Has the phenomenon of graduate unemployment come to stay? The answer to this question will be in the affirmative if the remedial measures to address this problem, as have been discussed in this paper, are not put in place by the government of Ghana and other players in the labour sector. One can confidently say that this worrying trend or development will not rear its ugly head again in the life of the nation if the government and other stakeholders pay much attention in addressing unemployment problems. Some of the measures discussed so far are: one, the government must roll out some interventions like Local Enterprises and Skills Development Programme (LESDEP), National Youth Employment Problem (NYEP), Savanna Accelerated Development Authority (SADA), Business Development Services Fund (BDFS) and the Gender Responsive Skills and Community Development Project (GRSCDP). Two, empowerment must be given to individuals, groups and communities through adult literacy and community development programmes carried out by adult educators. Three, co-operate bodies or the private enterprises must be innovative and create new jobs. Four, the unemployed graduates must also be innovative and 
create jobs for themselves and even employ others. Last but not the least, the curriculum of tertiary institutions, especially, the universities, must be reformed to focus on educating students on entrepreneurship and inculcating in them skills like communication, problem solving, creative thinking and innovation which can help the graduates establish their own businesses and become adaptable to new working environments.

\section{Recommendations}

- Adult educators should nurture the potentials of community people, especially, the graduates among the community people for the graduates to be the torch bearers in areas like entrepreneurship, health, education, conflict resolution and others. This will help the graduates in particular and the community in general to improve upon their quality of life.

- Polytechnics and Universities which are seen as adult educational institutions should limit the teaching of grammar and theoretical aspects of subjects and focus more on the teaching of entrepreneurship in other to nip in the bud the problem of graduate unemployment.

- Financial institutions have patrons or customers who are generally seen as adults. It stands to reason that if the financial institutions will be able to contribute their quota in curbing youth unemployment, they must give out soft loans to potential young entrepreneurs who may be graduates or not as a way of helping them to start their own businesses and to have a solid foundation for their businesses.

- Adult educational institutions must not rest on their oars in organizing more career guidance seminars, fora, workshops for unemployed graduates to upgrade their knowledge in entrepreneurship. This move taken by the adult educational institutions can go a long way to reduce the number of graduates who are jobless.

- Some unemployed graduates are still jobless because they have refused some job offers like teaching, farming and the like. They have also refused accepting jobs in some regions or districts in Ghana. The researcher will like to suggest or recommend to them to have a 
paradigm shift or change in attitude towards the types of jobs and their locations. An adherence to this admonition by some unemployed graduates will make them employed or land a job.

\section{Suggestions for further studies}

Based on the findings of this study, the researcher has the following suggestions for future researchers:

1. A comparative study of graduate unemployment could be conducted between the southern and northern parts of Ghana.

2. Again, a comparative study of graduate unemployment between two or more countries within West Africa could be conducted.

3. The research design of this paper is library research but several other research designs can be adopted by future researchers to conduct research on the current topic.

Acknowledgements: Augustine Adjei (Dean of Students)- Offinso College of Education, Mrs. Vida Boakyewaa Ampong, Elijah Boakye Ampong, Emmanuel Ampong Junior, Justice Adom-Adjei, Bridget Adom-Adjei, Herbert Adom-Adjei and Dominic Adom-Adjei

\section{References}

Abugri, S.A. (2011, September 16). A Crip dollar from Professor Aryeetey. Daily Graphic,p.7. BBC(2011, November 1). World's economy on verge of recession-ILO. The Ghanaian Times, P.6

Biney, I.K. (2015). Exploring graduate unemployment problem in Ghana: Challenges and Strategies. Journal of Education Vol. 3, No. 2. February, 2015. Retrieved August 5, 2020 from www.researchgate.net/publication/322301411.

Bindel, J. (2019). The real face of prostitution. Retrieved August 5, 2020 from www.truthdig.com/articles/the-real-face-of-prostitution/

Boateng, R., Olumide, L., Isabalija, R.S. \& Budu, J. (2011). Cyber Crime and criminality in Ghana: Its forms and implications. Journal of Information Technology Impact Vol.11 No. 2 pp.88100,2011. Retrieved August 6, 2020 from www.researchgate.net/publication/220889824 
Boye, A.C. (2012, March 24). Business development services fund. The Spectator, p.11.

Enyonam, D.T. (2017). Causes and effects of unemployment among the youth in the Ga West Municipality, Greater Accra Region. Unpublished Thesis, University of Ghana, Legon.

Gariba, S.A. (2012, June 5). High graduate unemployment. Daily Graphic, p.48.

Gender Desk (2013, March 4). Beneficiaries of GRSCDP scholarship show progress. Daily Graphic, p.11.

Lhayea, N.N. (2016). Application of routine activities theory to the study of residential armed robbery in Ghana. Theses and Dissertation paper 1008. Retrieved August 6, 2020 from www.openpraise.sdstate.edu/etd.

Pele, A. (2011). Youth and Entrepreneurship. In M. Tagoe\& O.T.F. Kwapong (Eds.) Report on the $62^{\text {nd }}$ annual new year school and conference. Accra: Ghana Universities Press, pp37-42.

Pillar, A.K. (2011). Essays for senior classes. New Dehli: Lotus Press.

Plecher, H. (2020). Unemployment rate in Ghana. Retrieved August 5, 2020 from www.statista.com/statistics/808481/unemployment-rate-in-ghana/

Ghana's youth employment rate (2011). Retrieved May 14, 2013, from en.wikipedia.org. /wiki/National-Youth-Employment-Programme.

Some Eurozone countries rate of unemployment (2013). Retrieved May 8, 2013 from www.dw.de.

Tankebe, J. and Boakye, K.E. (2019). Are murder and robbery on the increase in Ghana? Analysis of police crime statistics. Retrieved August 6, 2020 from www.africpgr.org/pressrelease/are-murder-and--

Tsekpo, A.K. (2014, March 8). What is Ghana's unemployment rate? Daily Graphic, P.7. 